УДК 68.41

DOI: 10.31453/kdu.ru.978-5-7913-1143-6-2020-164-170

Коколова Людмила Михайловна Kokolova Luidmila Michailovna доктор ветеринарных наук, заведующая лабораторией гельминтологии Doctor of veterinary sciences, managing the laboratory of helmintology

Гаврильева Любовь Юрьевна Gavrilieva Lubov Yurievna кандидат ветеринарных наук, старший научный сотрудник лаборатории гельминтологии candidate of veterinary sciences, senior staff scientist of laboratory of helmintology

Сивцева Евгения Владимировна Sivtseva Evgenia Vladimirovna аспирант лаборатории гельминтологии graduate student of laboratory of helmintology Якутский научно-исследовательский институт сельского хозяйства имени М.Г. Сафронова обособленное подразделение Федерального государственного бюджетного учреждения науки Федеральный исследовательский центр «Якутский научный центр,

Сибирского отделения Российской академии наук»

\title{
ИСТОРИЯ ИЗУЧЕНИЯ ПАРАЗИТАРНЫХ БОЛЕЗНЕЙ ЖИВОТНЫХ И СОВРЕМЕННАЯ ВЕТЕРИНАРНАЯ ПРАКТИКА В ЯКУТИИ
}

\section{HISTORY OF STUDYING PARASITIC ANIMAL DISEASES AND MODERN VETERINARY PRACTICE IN YAKUTIA}

Аннотация. Изучение распространения паразитарных болезней в Якутии берет свое начало с появление специалистов по ветеринарии с середины XIX века. В 1860 году было организовано ветеринарное управление. Но лишь в 1868 году правительство учредило совещательный ветеринарный комитет и ветеринарное отделение, оно было в ведении медицинского департамента при Министерстве внутренних дел. В 1864 году была организована земская ветеринария, ветеринарные врачи работали в сельской местности, обслуживая животноводство Якутии. Грюнер С.А. магистр ветеринарных наук, профессор, исследователь в области инфекционных болезней домашних животных, прибыл в Якутск и с 1906 работал областным ветеринарным инспектором в Якутии. Изучал состояние оленьих 
стад, диагностировал болезни северных оленей. Здесь он организовал ветеринарную лабораторию и изучал этиологию чесотки, финноза и других заболеваний у северных оленей. Описаны возбудитель чесотки у северных оленей, разработаны и предложены меры борьбы с этой болезнью.

Abstract: The study of distribution of parasitogenic illnesses in Yakutia takes beginning with appearance of specialists on veterinary science from middle the XIX century. A veterinary management was organized in 1860. But only in 1868 a government founded a deliberative veterinary committee and veterinary separation, it was in a conduct a medical department at Ministry of internal affairs. Земская veterinary science was organized in 1864, veterinary doctors worked in rural locality, serving the stock-raising of Yakutia. Gruner S.A. there is a master's degree of veterinary sciences, professor, researcher in area of infectious diseases of home animals, arrived to Yakutsk and from 1906 worked as a regional veterinary inspector in Yakutia. Studied the state of deer herds, diagnosed illnesses of reindeer. Here he organized a veterinary laboratory and studied etiology of scab, финноза and other diseases for reindeer. Described causative agent of scab for reindeer, the measures of fight are worked out and offer with this illnesses of reindeer. Here he organized a veterinary laboratory and studied etiology of scab, finnoz and other diseases for reindeer. Described causative agent of scab for reindeer, the measures of fight are worked out and offer against this illness.

Ключевые слова: история, паразитарные болезни, животные, ветеринария, практика, Якутия.

Key words: history, parasitic diseases, animals, veterinary medicine, practice, Yakutia.

В 1896 году случился большой падеж скота от сибирской язвы, особенно острый случай произошел на территории Усть-Алданского района. Поэтому первая прививка вакциной Пастера против сибирской язвы была проведена в 1897 году на 9 коровах и 20 лошадях Чериктяйского наслега Дюпсюнского улуса на средства населения. Уже через два года в этом же улусе были привиты 1019 голов скота, в Средневилюйском улусе в 21 пункте. С этого времени началась и до сих пор проводится плановые сибиреязвенные прививки, безусловно, очень небольшого количества, чем теперь.

Борьбу против падежа скота, лошадей и оленей, настойчиво обращался прибывший в Якутскую губернию Грюнер Сергей Александрович, он добился выделения средства для увеличения количества ветеринарных специалистов и их заработной платы. За всю историю до революционной Якутии мы находим одну 
работу Грюнера С.А. «Финноз северного оленя», вышедшую в 1909 году в этой работе автор дает описание финн, найденных у павшего оленя в Якутске. После Октябрьской революции академик К.И. Скрябин в 1931 году в работе «Глистные инвазии северного оленя» указывает на обнаружение Грюнером в 1927 г. в Якутии личиночную стадию эхинококка у оленей. В этом же году Союзная гельминтологическая экспедиция (СГЭ), наряду с изучением паразитических червей человека и домашних животных, в основном крупного рогатого скота и лошадей, исследовало пушных зверей песца-2, зайца-беляка- 2, белки-4, бурундука -5 , горностая - 1 . Результаты этих исследований мы встречаем в работах Р.С. Щульца (1931) «Паразитические черви кроликов и зайцев и вызываемые ими заболевания», А.М. Петрова (1941) «Глистные болезни пушных зверей». О.И. Скалон, 1938 год в статье «Значение паразитологии в охотпромысловом деле» нарду с глистной инвазией кишечника и желудка белок, впервые отмечает у них нематод в легких. К сожалению, легочные паразиты белки в то время так и остались не определенными, а собранный гельминтологический материал, очевидно пропал. В.Б. Дубинин в 1948 году описывает нематоду Syphacia sp. от ископаемого суслика Citellus glacialis Vinogr., найденного в пойме одного из притоков р. Индигирки. В.И. Белых в 1953 году «В материалах по экологии якутской белки» указывает наличие у белок большого количества кишечных нематод и крупных нематод, достигающих 30 мм, обитающих в желудке. Первых нематод из кишечника она относила к анкилостомам, вторые в желудке оставила без определения. Хотя сборы эти не сохранились, но в последующем было выяснено, что кишечные гельминты относятся к оксиуратам и скорее всего к виду Syphacia trompsoni, а желудочные нематоды относятся роду Mastophorus. В Якутии, предполагаемые В.И. Белых анколостомы в единичных экземплярах встречаются у небольшого числа представителей псовых. Н.М. Губановым Н. в 1956 году изучена биология цестоды Taenia macrocystis (Diesing, 1850), в 1958 зараженность грызунов Якутии личиночными стадиями цестод, а также в 1960 году зараженность альвеококком хищных млекопитающих и мышевидных грызунов в Якутии. 
Результаты проведенной 100-й Союзной гельминтологической экспедиции дает сводку гельминтофауны домашних животных и рассматривает динамику ее по годам и сезонам и они были отражены в 1955 году в кандидатской диссертации М.Г. Сафронова «Гельминты и гельминтозы сельскохозяйственных животных в Якутской АССР». В последующих работах, М.Г. Сафронова 1958, 1960, 1961, 1963 занимался вопросами изучения краевой эпизоотологии названных инвазий животных в Якутии. М.Г. Сафронов в 1958a, 1959 годах описывает биологию диктиокаулюсов и альвеококка животных в Якутии, изучает фауна гельминтов домашнего северного оленя и ее профилактику.

Изучением эпидемиологии альвеолярного эхинококкоза и заболеванием населения Якутии занимались В.С. Семенов в 1953, Г.А. Бежаев в 1959, С.О. Мигалкин в 1960, П.П. Габышев в 1961 у и Б.И. Альперович в 1972.

С.И. Исаков, Л.М. Коколова по результатам научных исследований 19892007 гг. установили, что основным источником возбудителя гидатидного эхинококкоза являются не сельскохозяйственные животные, а дикие копытные и, в частности, лоси, а также, возможно, другие виды семейства оленьих. Альвеолярный эхинококкоз и эхинококкоз гидатитозный распространены, как среди копытных животных, так и у людей. Однако основным источником возбудителя эхинококкоза и альвеококкоза считают домашних собак, которые заражались, поедая внутренние органы сельскохозяйственных животных, пораженных ларвальными эхинококками и мышевидных грызунов, инвазированных альвеококками. Следовательно, возникла необходимость подробного изучения экстенсивности и интенсивности инвазии диких копытных эхинококками и их роли в инвазировании населения и домашних животных. Исходя из этих принципов, приоритетной задачей ветеринарной службы является всемерное содействие развитию агропромышленного комплекса, обеспечение населения безопасной и качественной продукцией животноводства. Наш научный институт заинтересован сотрудничеству со службами и ведомствами ветеринарной службы и хозяйствующими субъектами. Развитие агропромышленного комплекса возможно только в условиях стабильного 
эпизоотического благополучия, в связи с этим своевременное и качественное проведение комплекса противоэпизоотических и лечебно-профилактических мероприятий, направленных на предупреждение и ликвидацию инвазионных болезней обеспечивает сохранность поголовья животных, увеличения и улучшение качества продукции животноводства. Всего по Республике Саха (Якутия) зарегистрированы более 33 болезней общих для человека и животных, более 36 инфекционных болезней сельскохозяйственных животных, а также зарегистрированы около 220 наименований незаразных болезней всех видов животных. Ежегодно ветеринарная служба республики проводит ветеринарносанитарную экспертизу мяса, других мясных продуктов на убойных пунктах хозяйств, на мясоперерабатывающих предприятиях и на рынках. Тем не менее, в последние годы вопрос по зараженности паразитарными болезнями животных стоит остро, эффективность и результативность оздоровления от гельминтозоонозов зависит, прежде всего, от координированных совместных действий не только ветеринарных специалистов, исследователей, но и всех структур, имеющих отношения к животноводству.

В заключение следует отметить о необходимости проведения широкомасштабных научно-исследовательских работ по изучению и борьбе с опасными гельминтозоонозами с учетом природно-климатических, хозяйственных и социально-экономических условий региона. Для этого необходимо проведение обязательных гельминтологических исследований домашних животных и добытых промысловых животных, ветеринарносанитарный осмотр всех убойных домашних животных. Обязательные лечебнопрофилактические и оздоровительные мероприятия безусловно направлены для защиты здоровья населения. Для повышения уровня экологической и санитарногигиенической культуры населения необходимо вести целенаправленную работу с использованием средств массовой информации, информировать об особенностях распространения зоонозов и соблюдении правил личной гигиены. 


\section{Библиографический список:}

1. Грюнер С. А. 1910. Финноз северного оленя. - Архив, вет. наук, кн. 8.

2. Грюнер С. А. 1912. Финноз у северных оленей в Аляске (автореф.). Архив вет. наук, кн. 4.

3. Грюнер С. А. 1914. Оленеводство в Аляске (окончание). - Архив вет. наук, кн. 12.

4. ГрюнерС.А. 1927. Эхинококки у северных оленей. - Труды Сибирск. вет. института, вып. VIII.

5. Грюнер С. А. 1930. Случай недоразвития и перерождения финн у северного оленя. Вестник соврем, ветерин., № 13-14.

6. Губанов Н. М. 1956. К биологии цестоды Taenia macrocystis (Diesing, 1850). - Уч. зап. Моск. гос. пед. института им. В. И. Ленина, т. 46, вып. VI. С 54.

7. Губанов Н. М. 1958. Зараженность грызунов Якутии личиночными стадиями цестод. - Научн. сообщ; Якутск, филиала АН СССР, вып. 1. С.18.

8. Губанов Н. М. 1960. Зараженность альвеококком хищных млекопитающих и мышевидных грызунов в Якутии. Тезисы доклада научной конференции ВОГ. М. 1960. С. 41-42.

9. Исаков С.И., Сафронов М.Г. Эхинококкоз и альвеококкоз животных в Якутии / С.И. Исаков, М.Г. Сафронов // Научн.- практ. семинар «Перспективы ликвидации потерь от эхинококкоза в животноводстве» Тезисы докладов. г. Фрунзе, 14-16 окт.1987. - Москва. - 1987. - С.23.

10. Коколова Л.М. Особенности распространение зоонозных гельминтозов на Крайнем Севере./ Л.М. Коколова // Труды Всерос. ин-та гельминтол.- М.: Россельхозакадемия, т.41. - 2006. - С.91-96.

11. Коколова Л.М. Эпизоотология, эпидемиология и меры борьбы с гельминтозами в Якутии //Автореферат диссертации на соиск. уч. ст. докт. вет. наук, М.: -2007 C. 46.

12. Контримавичус В.Л. и Попов М. В. 1956. Динамика зараженности гельминтами и латентные гельминтозы зайца-беляка Якутии. - Уч. зап. Моск. гос. пед. института им. В. И. Ленина, т. 46, вып. 6. С 13-19. 
13. Обгольц А.А., Клебановская И.А., Клебановский В.А., Смирнов П.Л. О природной очаговости эхинококкоза на Таймыре. - Мед. паразитология и паразитар.болезни, - 1980.- - №5 - 56-60 с.

14. Петров А. М. 1932. К фауне паразитических червей домашних плотоядных Сибирского края. - Труды 50-й Союзн. гельминт, экспедиции в Сибирский край.

15. Сафронов М. Г. 1955. Гельминты и гельминтозы сельскохозяйственных животных в Якутской АССР. (Канд. дисс.) М., Библиотека ВИГИС. 24 с.

16. Сафронов М. Г. 1958. Гельминтофауна сельскохозяйственных животных в Якутской АССР. - Труды Якутск, научно-иссл. вет. станции, вып. 1. C 78-93.

17. Сафронов М. Г. 1958а. Роль собак в распространении эхинококкозов и цистицеркозов среди сельскохозяйственных животных и населения в Якутской АССР. - Труды Якутск, научно-иссл. вет. станции, вып. 1. С. 120-126.

18. Сафронов М. Г. 1959. О видовом составе возбудителей эхинококкозов животных и человека в Якутской АССР, Работы по гельминт. К 80-летию акад. К. И. Скрябина, вып. 1. М., Изд-во АН СССР. С. 196-199.

19. Сафронов М. Г. 1960. О гельминтофауне оленей в Томпонском и Олеиекском районах Якутской АССР. - Труды Якутск, научно-иссл. института сельск. хоз-ва, вып.. III. С.103-106.

20. Сафронов М. Г. 1961. О видовом составе возбудителей эхинококкозов животных и человека в Якутской АССР (Сообщ. 2). - Труды Иркутск. научноиссл. института с.-х., вып. 4.С.58-59. 